\title{
Pourriotia carcharodonta, a new genus and species of monogonont rotifer from subantarctic Îles Kerguelen (Terres Australes et Antarctiques Françaises)
}

\author{
W.H. De Smet
}

University of Antwerp, R.U.C.A.-campus, Department of Biology, Section Polar Ecology, Limnology and Palaeobiology. Groenenborgerlaan 171, B-2020 Antwerpen, Belgium. E-mail : wides@ruca.ua.ac.be

\begin{abstract}
Pourriotia carcharodonta gen. et sp. nov. is described from freshwater plankton collected at the subantarctic Kerguelen islands. The new taxon is provisionally placed in the Notommatidae. Main diagnostic characters separating the new taxon and the other genera of the family are provided by the morphology of the trophi. Apical rami chambers with toothed inner margin and blunt projection on outer margin. Apical rami teeth and subuncinal teeth with accessory spines. Proximal margin of major uncinal teeth firmly connected to distal margin of apical chambers, forming grasping unit. Fulcrum dumb-bell-shaped. Information is presented on the trophi structure of the genus Pleurata (Notommatidae).
\end{abstract}

Keywords : Rotifera, Notommatidae, Pourriotia carcharodonta, new genus, new species, Kerguelen Islands, subantarctica, freshwater, Pleurata.

\section{Introduction}

The subantarctic Kerguelen archipelago (48 $58^{\prime}$ $\left.49^{\circ} 73^{\prime} \mathrm{S}, 68^{\circ} 72^{\prime}-70^{\circ} 58^{\prime} \mathrm{E}\right)$ is part of the Terres Australes et Antarctiques Françaises (T.A.A.F.). It is situated in the Southern Indian Ocean (Fig. 1), c. $5000 \mathrm{~km}$ from South Africa and Australia, and c. $2000 \mathrm{~km}$ from the Antarctic Continent. The area is characterized by a cold temperate climate with a strong maritime influence (Stonehouse 1982). A recent study on the plankton rotifers from some freshwater habitats at the main island Grande Terre (De Smet 2001), revealed 38 monogonont taxa, of which 33 were new records for Îles Kerguelen. Among these taxa were two species listed as «Incertae sedis». One of them was represented by a sufficient number of specimens to be described in detail herein.

\section{Material and methods}

Lac Supérieur (formerly called Lac Studer 1) is located (Fig. 1) in the valley Val Studer, some $15 \mathrm{~km}$
WNW from the base Port-aux-Français, at an altitude of 70-80 $\mathrm{m}$ a.s.l. and a distance of $7.4 \mathrm{~km}$ from the sea. It is a fairly large lake with a surface area of 84.6 $10^{4} \mathrm{~m}^{2}$, and an average depth of $23 \mathrm{~m}$. According to Maire (1985) it is oligotrophic, neutral to weakly alkaline with buffering capacity almost zero. It is thoroughly mixed up to its maximum depth of $43 \mathrm{~m}$, and never stratified due to the continuing strong winds and the small amplitude of the watertemperature. Littoral samples (plankton, submerged mosses, hygropsammon, Aufwuchs) were sampled in February 1998 and January 2002, in the southern corner of the lake, off the cabins. Plankton was collected by a horizontal haul, using a $40 \mu \mathrm{m}$ mesh plankton net. All samples were fixed on the spot with formalin up to a concentration of $3 \%$. Animals were examined and drawn with a Leitz Orthoplan microscope equipped with camera lucida. Preparation of trophi for light and scanning electron microscopy (SEM) was done following De Smet (1998), using dilute $\mathrm{NaOCl}$ solution. SEM was performed with a Philips SEM 515 microscope operated at $20 \mathrm{kV}$. 


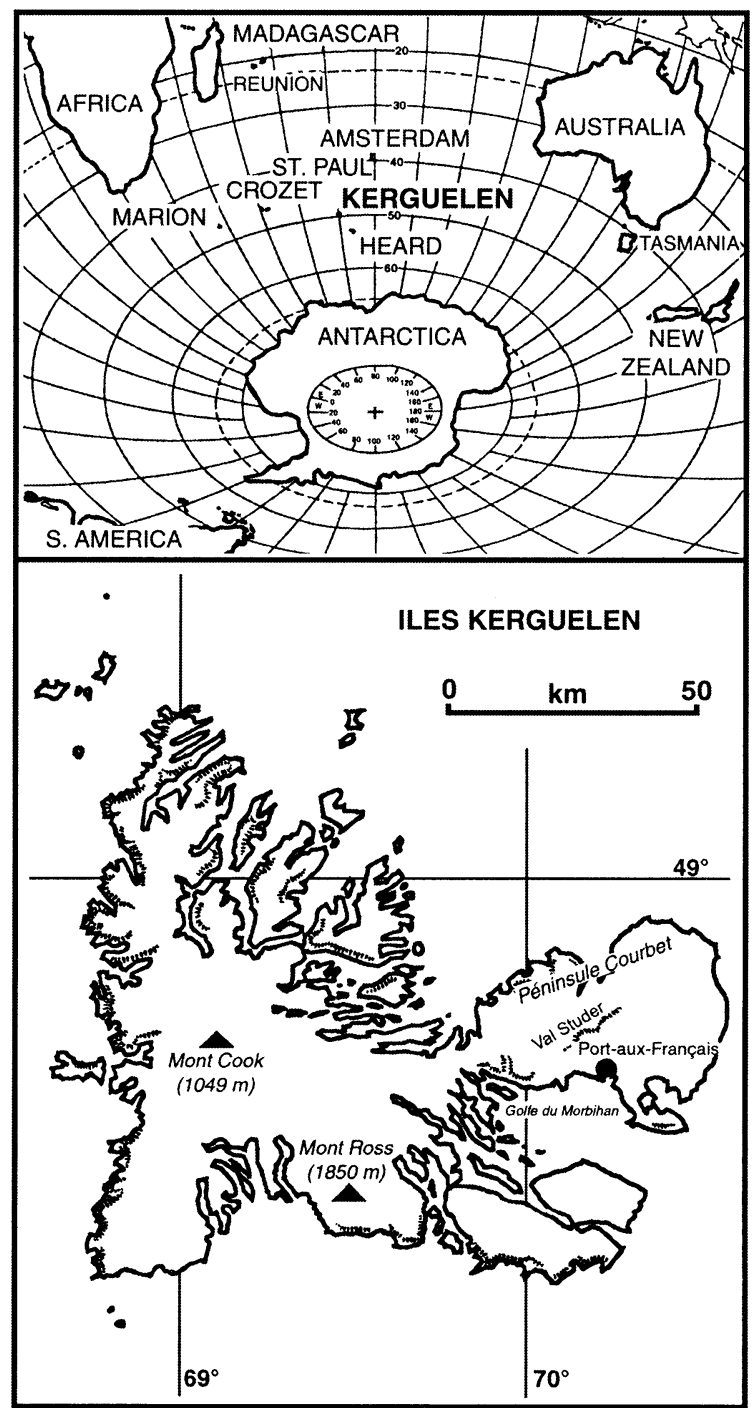

Fig. 1. Upper : map showing Îles Kerguelen in relation to the continents and some other subantarctic islands. Lower : map of Îles Kerguelen with sampling area of the Val Studer indicated.

\section{Description of new genus and species}

\section{Pourriotia gen. nov.}

Type species

Pourriotia carcharodonta sp. nov., by monotypy.

Etymology

The genus is dedicated to Prof. Dr. Roger Pourriot, in recognition of his important contributions to the study of Rotifera.

\section{Diagnosis}

Body elongated, illoricate. Corona strongly oblique. Head with pseudorostrum. Foot terminal, with short toes. Subcerebral glands present. Three salivary glands : one contained in mastax distally, two large pyriform and stalked laterally. Trophi modified virgate. Rami with elongate basal and subbasal chambers, and apical chambers with toothed inner margin and blunt projection on outer margin. Apical rami teeth with accessory spines. Fulcrum dumb-bell like in dorsal/ventral view. Unci firmly connected to apical chambers, forming grasping unit. Subunci present, teeth with accessory spines. Head of manubria composed of three chambers. Epipharynx two large bootshaped plates.

The new taxon can not be confused with any other genus.

Pourriotia carcharodonta gen. et sp. nov. (Figs. 217)

\section{Material examined}

Holotype : a parthenogenetic female in a permanent, glycerin glass slide mount deposited in the Koninklijk Belgisch Instituut voor Natuurwetenschappen (K.B.I.N.), Brussels, reg. nr. I.G. 29.824, RIR145.

Paratypes : one slide with one paratype in K.B.I.N., reg. nr. I.G. 29.824, RIR146 ; 6 slides with one parthenogenetic female, and 2 stubs each with one trophi preparation for SEM in the Department of Biology, University of Antwerpen.

\section{Type locality}

Lac Supérieur (formerly called Lac Studer 1) in valley Val Studer, Courbet peninsula, Grande Terre, Îles Kerguelen, Southern Indian Ocean (T.A.A.F.). Obtained from littoral plankton taken near cabins on $4 \mathrm{Fe}$ bruary 1998.

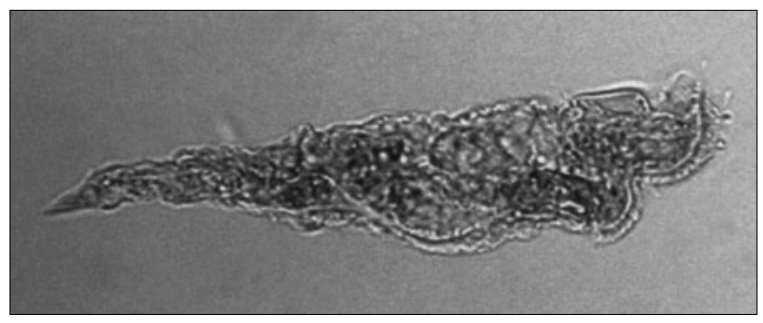

Fig. 2. Pourriotia carcharodonta gen. et sp. nov., holotype lateral view. 


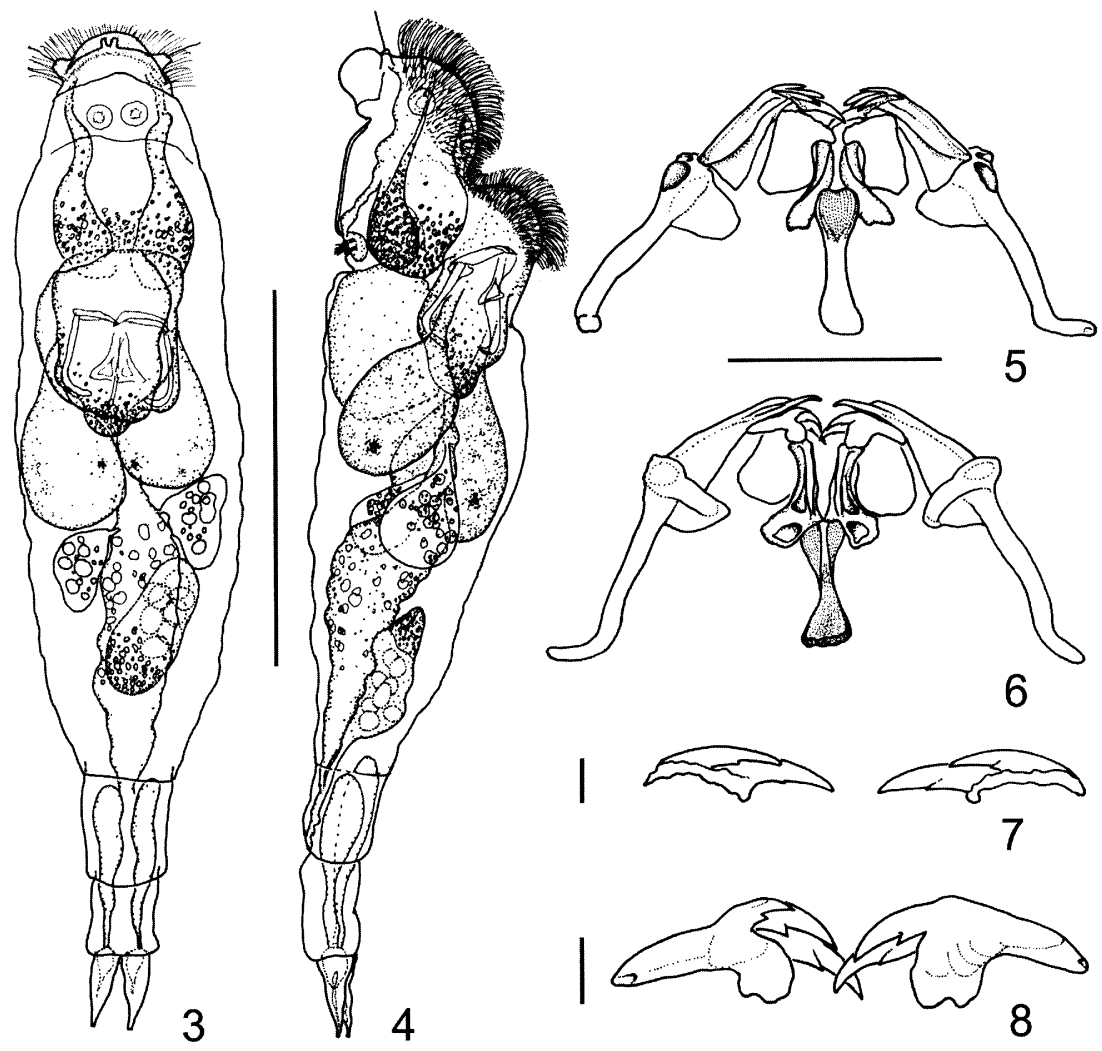

Figs. 3-8. Pourriotia carcharodonta gen. et sp. nov., female. 3. dorsal view, 4. lateral view, 5. trophi, ventral view, 6. trophi, dorsal view, 7. subunci, 8. apical rami chambers. Scale bar : 3, $4: 50 \mu \mathrm{m}, 5$, $6: 10 \mu \mathrm{m}, 7,8: 1 \mu \mathrm{m}$.

\section{Etymology}

The specific name carcharodonta is derived from the Greek «karcharodous», meaning with sharp teeth, and refers to the shape of the unci, subunci and apical rami teeth.

\section{Description}

Female (Figs 2-4). Cuticle soft. Body fusiform in dorsal view, broadest near mid length ; in lateral view more or less conical. Head continuous with trunk, large, about $1 / 3$ of total length, with vesicle-shaped pseudorostrum. Corona strongly oblique, with ventral indentation near middle, mouth opening at posterior margin ; auricles absent. A short papilla with long cilia laterally on both sides of pseudorostrum. Some specimens with two close-set small papillae antero-medially. Dorsal antenna in depression near posterior of brain. Trunk without distinct folds, broadest anteriorly, more or less gradually narrowing to foot ; tail indistinct. Lateral antennae not seen. Foot medium long, $c$. $1 / 5$ of total length, with two cylindrical pseudosegments of equal length. Toes equal, $c$. 1/12-1/15 total length, almost conical, inner and ventral margins slightly undulate in dorsal and lateral view respectively ; tips of toes tubular. Two large colourless frontal eyespots. Brain large, saccate. Retrocerebral sac very large, at posterior of brain. Subcerebral glands large. The outlets of the ducts of the retrocerebral sac and/or subcerebral glands probably opening through the antero-median papillae. Mastax with three salivary glands : a single one contained in the mastax wall and bulging posteriorly, and two large stalked pyriform glands laterally from mastax, almost extending to middle of body. Stomach and intestine not separated by constriction. Gastric glands roundish to rounded triangular, short-stalked. A well-differentiated bladder is apparently absent. 


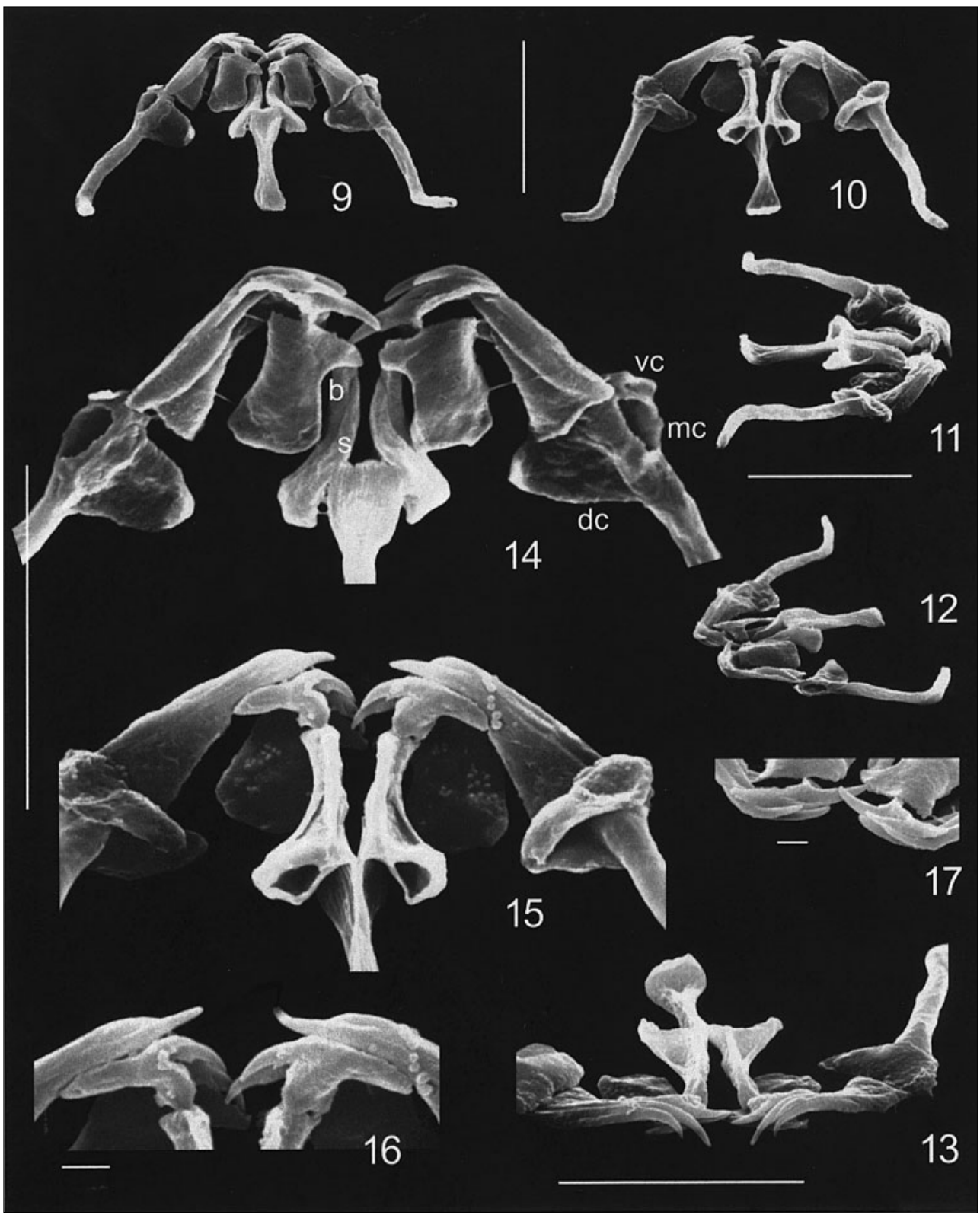

Figs. 9-17. Pourriotia carcharodonta gen. et sp. nov., trophi, SEM photographs. 9. complete set of trophi, ventral view, 10. ibidem, dorsal view, 11. ibidem, dorso-lateral view, 12. ibidem, ventro-lateral view, 13. complete set of trophi, dorso-apical view, 14. detail, ventral view, 15. detail, dorsal view, 16. apical rami chambers, dorsal view, 17. subunci, ventral view. $\mathrm{b}:$ basal ramus chamber, $\mathrm{s}:$ subbasal ramus chamber, dc : dorsal manubrial chamber, mc : medial manubrial chamber, vc : ventral manubrial chamber. Scale bars : 9-15:10 $\mu \mathrm{m}, 16,17: 1 \mu \mathrm{m}$. 
Pedal glands club-shaped, foot length. Vitellarium with 8 nuclei.

Trophi (Figs. 5-17) modified virgate, small, almost symmetrical. Rami and fulcrum lying in the same plane ; the mallei form a fairly small angle with the incus. Rami outline lyrate. Rami more or less flat, not recurved dorsally, with conspicuous apical, basal, and subbasal chambers ; small alulae. Basal and subbasal chambers elongate (b, s ; Figs. 14, 15). Opening of subbasal chambers rounded, opening of basal chambers elongate-triangular (Fig. 15). Inner margins of basal and subbasal chambers without teeth; a distinct longitudinal crest extending over the whole length of the rami dorsally. Apical chambers (Figs. 8, 16) with superimposed teeth on inner margin, and blunt projection on outer margin. Teeth composed of 3 (left) or 2 (right) curved sharp teeth, each with small accessory toothlet at their base ; ventral teeth smallest. Distal margin of lateral projections firmly connected to proximal margin of head of major uncinal teeth by ligaments ; lateral projections apparently with small opening laterally. The basal part of the apical chambers shows a small indentation near the juncture with the basal chamber. Fulcrum pointing towards posterior, ramus length, outline dumb-bell-shaped in dorsal view. The broadened distal end is terminally rounded, recurved dorsally and spoon-shaped ; its ventral surface is smoothly rounded. The broadened proximal end is more or less triangular, slightly hollow ventrally and keeled dorsally ; its composing sclerite bodies are coarse and distinct. Unci long, c. 2/3 manubrium length, plate-shaped, composed of almost completely fused teeth with free head, and subuncus. Two (right) to three (left) sharp and incurved teeth of unequal length : ventral teeth smallest ; teeth tapering, without offset head. Inner side of unci with prominent rib. Dorso-basal part of unci broadening towards manubria. Subunci (Figs. $7,17)$ composed of two slightly curved teeth of unequal length connected basally ; each tooth bears a weakly developed accessory spine. Manubria approximately incus length, rod-shaped with short triangular head composed of ventral, medial and dorsal chambers (vc, mc, dc ; Figs. 14), and ventrally decurved cauda ; ventral chamber smallest ; opening of ventral and medial chambers ventrally at inner side of manubria, opening of dorsal chamber at outer side (Figs. 14, 15). The epipharynx consists of two large boot-shaped plates ventrally from rami (Fig. 14) ; plates connected to unci by ligaments.

\section{Measurements}

$(\mathrm{N}=10)$ Total length 123-164 $\mu \mathrm{m}$, toe 10-11 $\mu \mathrm{m}$; $(\mathrm{N}=2)$ trophi $12-13 \mu \mathrm{m}$, ramus $6.5-6.8 \mu \mathrm{m}$, apical ra- mus chamber 3.8-3.9 x 1.6-1.7 $\mu \mathrm{m}$, fulcrum 6.2-6.9 $\mu \mathrm{m}$, uncus 6.5-7 $\mu \mathrm{m}$, manubrium 10-11 $\mu \mathrm{m}$, apical chamber 3.8-3.9 x 1.6-1.7 $\mu \mathrm{m}$, subuncus 4.4-4.7 $\mu \mathrm{m}$, epipharynx plate $3.7-4 \mu \mathrm{m}$.

\section{Comments}

The new taxon shows a combination of peculiar characters which make its affiliation problematical. The well developed retrocerebral apparatus is of the $\mathrm{No}$ tommata-type, and the corona likewise reminds of the Notommatidae (de Beauchamp 1907, 1965). The trophi apparently possess elements of both the virgate type, as found in Notommatidae, and the forcipate type, characteristic of the Dicranophoridae. A fairly long fulcrum, distally enlarged for the attachment of the hypopharyngeal muscle, is a feature common to many Notommatidae. However, the dumb-bell shape as found in the new species is unique ; a similarly enlarged spoon-shaped distal end of the fulcrum is found only in Rousseletia corniculata Harring, 1914. The enlarged proximal part of the dumb-bell-shaped fulcrum in Pourriotia suggests the presence also of well developed abductor muscles, connected to the posterior edges of the rami and the alulae, as found in Dicranophoridae. Up till now, large epipharyngeal plates in the ventro-lateral walls of the mastax were reported in the notommatid genus Pleurata only. Unci displaying two or more teeth, likewise are common to many notommatids, although SEM has shown (De Smet 1997, and unpubl.) that a tooth formula of 2-3/3-3 is not rare in Dicranophorus too, where it is a plesiomorphic trait. Tapering uncinal teeth without offset head are found in both families. Rami lying in the same plane as the fulcrum, is one of the main characters of the forcipate trophi of Dicranophoridae, although it is to be found in some notommatids too. Dorso-ventrally flattened and elongate basal and subbasal chambers, a common feature in dicranophorids, are shared with some notommatids (e.g. Pleurata Figs. 18, 19). Similarly to dicranophorids (e.g. Dicranophoroides trophi in De Smet 1997 : Plate 1), the rami are terminated by an apical chamber bearing teeth at their inner margin. The accessory spines, shown by the teeth of the apical chambers and subunci, have not been demonstrated in any other rotifer taxon. The unci are firmly connected to the distal margins of the apical chambers, and form a grasping unit. The lateral projections of the apical chambers are interpreted as a specialisation, allowing for a broader attachment to the unci. This situation whereby the unci are fused to the apical chambers or rami tips is absent in Notommatidae (with the exception of Tylotrocha monopus (Jennings, 1894) ?), where unci are hinged ventrally to the rami(tips). In Tylotro- 
cha the mallei and rami are fused to a dome-shaped structure, with mallei no longer divisible in unci and manubria (Harring \& Myers 1924). However, SEM investigations are required as unci may also be absent (see e.g. Dorystoma, Rousseletia). A fusion between unci and rami is seldomly encountered in Dicranophoridae (Parencentrum, ? Myersinella), which usually show unci pivoting on the rami tips or bases of the ramus lock.

The characteristics of Pourriotia are largely intermediate between those of Notommatidae and Dicranophoridae. However, the forcipate trophi of the latter lost their pumping action and became adapted for prehension only. The new taxon possesses trophi with both virgate fulcrum and rami forming pincers in their anterior part, as found in many genera within Notommatidae, and hence it is placed in this family. However, seeing that the Notommatidae is an unsatisfactory assemblage of diverse taxa (Nogrady et al. 1995) and almost surely polyphyletic, the allocation of Pourriotia should be considered provisional, and reevaluated when new information, in particular sequencing analysis, becomes available.

The vesicle-shaped pseudorostrum of unknown function is very rare in Rotifera, and has only been observed in Wulfertia kindensis (Proalidae) described from Birma by Koste \& Tobias (1990).

The trophi of Pourriotia show a superficial resemblance with those of some members of the genus Pleurata (Notommatidae). The latter genus was established by Nogrady \& Pourriot (Nogrady et al. 1995) to accommodate Notommata tithasa Harring \& Myers, 1922, N. trypeta Harring \& Myers, 1922, N. tyleri Koste, Shiel \& Tan, 1988, Pleurotrocha chalicodis Myers, 1933, P. thura Myers, 1933 and P. vernalis Wulfert, 1935, and should include Proales uroglenae de Beauchamp, 1948 also (De Smet 1996). However, the trophi of $P$. tithasa and $P$. thura are very different, which suggests that both species should not be retained in Pleurata; the other members of the genus are referred as Pleurata s. str. hereafter. Close analysis reveals important differences between Pleurata s. str. and Pourriotia. Pleurata s. str. lacks the characteristic toothed apical chambers of Pourriotia. The unci are small and weakly developed in Pleurata s. str. (the uncinal apparatus of the species shown in Figs. 21-22 with 5-6 short and loosely bound teeth and 1-2 long, rod-shaped elements). The fulcrum in Pleurata s. str. is almost rodshaped and slightly expanding distally in dorsal view, instead of dumb-bell-like with spoon-shaped end distally. Moreover the fulcrum of the species shown in Fig. 18-22 displays an opening distally, which is ab- sent in the new taxon. Another important difference between both taxa is in the morphology of the manubria. Those of Pourriotia have an almost straight, rodshaped shaft with incurved caudum, and short head composed of three chambers each with opening. The manubria in Pleurata s. str. are more or less curved with flattened head composed of elongated medial and dorsal chambers (mc, dc ; Figs. 21), and a distinctive lamellar ventral chamber (vc ; Figs. 18-20), located medially or more distally according as the species. The opening of the medial chamber is situated on a level with or distally to (om ; Fig. 20) the ventral chamber, depending on the species. Both Pleurata s. str. and Pourriotia show very large epipharyngeal plates, a feature not found in other rotifer species. Some relevant taxonomic differences at the generic level concerning the soft body parts are obvious also. Pourriotia has two frontal eyespots, and Pleurata s. str. is provided with a cerebral eye (reported absent in $P$. tyleri by Nogrady et al. (1995), but apparently shown in Fig. 15b in Koste et al. (1988)). Subcerebral glands and a pseudorostrum are present in Pourriotia only. Other features distinguishing the two genera are the slender and less sclerified trophi (Figs. 18-22) and distinct alulae in Pleurata s. str., and the large and stalked lateral salivary glands present in the new taxon but absent in Pleurata s. str.

Distribution and ecology

Specimens of Pourriotia carcharodonta were obtained in low numbers from littoral plankton of lake Supérieur. It could not be found in other samples including submerged mosses, Aufwuchs consisting of filamentous algae, and hygropsammon taken at the sampling site. The species was found during the sampling campaign of February 1998 only. An intensive sampling effort of different habitats at the type locality in 2002 did not yield a single specimen. The bottom at the sampling site was stony with gravel and some submerged mosses. Watertemperature $11^{\circ} \mathrm{C}, \mathrm{pH} 7.5$, conductivity $60 \mu \mathrm{S} \mathrm{cm}-1$, total alkalinity titer $0.24 \mathrm{mmol} \mathrm{l}^{-1}$. No food items were observed in the stomach or intestine. The species was accompanied by a fairly rich rotifer fauna dominated by Keratella sancta Russell, and crustaceans with the copepod Pseudoboeckella volucris Kiefer as dominant (De Smet, 2001). The phytoplankton was characterized by $\mathrm{Bo}$ tryococcus braunii Kützing and Mougeotia sp.

The shape of the trophi suggest that the new taxon might be a predator or ectoparasite. The peculiar apical rami chambers with their sharp curved teeth, may function in the attachment to or holding of some organism. The long and distally spoon-like enlarged ful- 


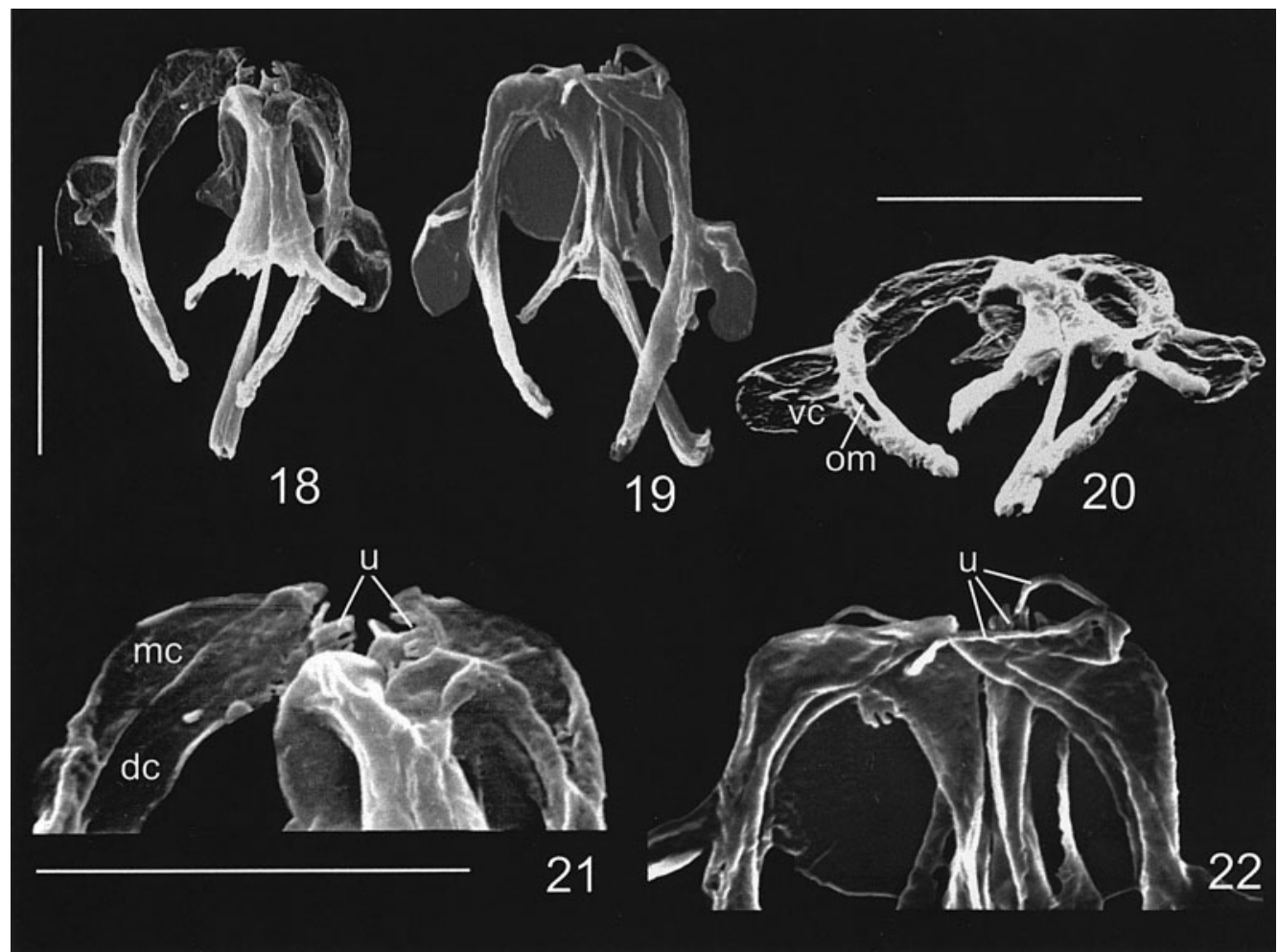

Figs. 18-22. Pleurata (s.str.) sp., trophi, SEM photographs. 18. complete set of trophi, ventral view, 19. ibidem, dorsal view, 20. ibidem, ventro-caudal view, 21. detail, dorso-apical region, 22. detail, ventro-apical region. dc : dorsal manubrial chamber, mc : medial manubrial chamber, vc : ventral manubrial chamber, om : opening of medial chamber, $\mathrm{u}$ : uncinal apparatus. Scale bars : $10 \mu \mathrm{m}$.

crum, and the large epipharyngeal plates supporting the ventro-lateral walls of the mastax are evidence of a strong pumping action to suck out the contents of some prey or host.

\section{Acknowledgements}

I gratefully acknowledge the «Institut Polaire Français» for the logistic and financial support, and the Science Foundation Flanders (F.W.O.) for additional funding. The present study is part of the Terrestrial Ecology Program Biosol no 136 (Dr. Y. Frenot, Station Biologique Paimpont). The Laboratory of Cell Biology and Histology provided the necessary SEM facilities.

\section{References}

de Beauchamp P. 1907. — Morphologie et variations de l'appareil rotateur dans la série des Rotifères. Arch. Zool. expér., $6: 1-29$

de Beauchamp P. 1965. — Classe des Rotifères. In P-P. Grassé : Traité de Zoologie. Némathelminthes (Nématodes, Gordiacés),
Rotifères, Gastrotriches, Kinorhynques. T. IV(3). Masson et Cie., Paris : $1225-1379$

De Smet W.H. 1996. — Rotifera 4 : The Proalidae (Monogononta). In H.J. Dumont \& T. Nogrady (eds.) : Guides to the Identification of the Microinvertebrates of the Continental Waters of the World 12. SPB Academic Publishing, The Hague, The Netherlands : $102 \mathrm{p}$.

De Smet W.H. 1998. — Preparation of rotifer trophi for light and scanning electron microscopy. Hydrobiologia, 387/388 (Developm. Hydrobiol., 134) : 117-121.

De Smet W.H. 2001. - Freshwater Rotifera from plankton of the Kerguelen Islands (Subantarctica). Hydrobiologia, 446/447 (Developm. Hydrobiol., 153) : 261-272.

De Smet W.H. 1997. — Dicranophoridae. In De Smet, W.H. and R. Pourriot, Rotifera 5 : The Dicranophoridae (Monogononta) and the Ituridae (Monogononta). Guides to the Identification of the Microinvertebrates of the Continental Waters of the World 12, H.J. Dumont \& T. Nogrady (eds.) : SPB Academic Publishing, The Hague, The Netherlands : $344 \mathrm{p}$.

Harring H.K. \& Myers F.J. 1924. - The rotifer fauna of Wisconsin. II. A revision of the notommatid rotifers, exclusive of the Dicra- 
nophorinae. Trans. Wiscons. Acad. Sc., Arts, Lett., 21 : 414-549, pl. 16-43.

Koste W., Shiel R.J. \& Tan L.W. 1988. - New rotifers (Rotifera) from Tasmania. Trans. R. Soc. S. Aust., 112 : 119-131.

Koste W. \& Tobias W. 1990. —Zur Kenntnis der Rädertierfauna des Kinda-Stausees in Zentral-Burma (Aschelminthes : Rotatoria). Osnabrück. naturwiss. Mitt., $16: 83-110$.

Maire P. 1985. - Contribution à l'étude hydrobiologique du Lac Studer, écologie du phytoplancton et production primaire. Îles Kerguelen, Terres Australes et Antarctiques Françaises. Thèse. Université de Metz : $126 \mathrm{p}$.
Nogrady T., Pourriot R. \& Segers H. 1995. - Rotifera 3 : The Notommatidae and the Scaridiidae. In H.J. Dumont \& T. Nogrady (eds.) : Guides to the Identification of the Microinvertebrates of the Continental Waters of the World 8. SPB Academic Publishing, The Hague, The Netherlands : $248 \mathrm{p}$.

Stonehouse B. 1982. - La zonation écologique sous les hautes latitudes australes. C.N.F.R.A., $51: 531-537$. 